\title{
Macrocyclic Chemistry
}

\section{Tapashi Ghosh Roy*}

University of Chittagong, Chittagong, Bangladesh

*Corresponding Author: Tapashi Ghosh Roy, University of Chittagong, Chittagong, Bangladesh.
Received: February 04, 2020

Published: February 18, 2020

(C) All rights are reserved by Tapashi Ghosh

Roy.
Scientists are focusing their research interest in Macrocyclic Chemistry due to its multifarious applications in various sectors. Research on Macrocyclic Chemistry generally covers all aspects of host-guest systems. A major new trend in this area is to incorporate heteroatoms into the cyclic backbone which can function as ligands for metal complexation. Studies on macrocyclic compounds represent an important area of activity which impinges on a range of other area in both Chemistry and Biochemistry. Coordination Chemistry of macrocyclic componds has been a engrossing area of current research interest to the chemists all over the world. The first macrocyclic compound prepared from a diacid was dimeric ethylene succinate reported by Vorlander in 1894. The macrocyclic ligands and their metal complexes involved in a number of fundamental biological systems have long been recognized. Synthetic tetraazamacrocyclic ligands, their $\mathrm{N}$-pendent derivatives and their different metal complexes have attained a remarkable attention to the researchers due to their multidisciplinary applications. They have found wide applications as antitumor, anticancer, antibacterial and antifungal agents. Macrocyclic natural products have evolved to fulfill numerous biochemical functions, and their profound pharmacological properties have led to their development towards pharmaceuticals. Due to the facile incorporation of metal ions in the cavity of the macrocyclic ligands these types of compounds remarkably used in the medicinal chemistry area as well as in the sector of drug discovery. Macrocyclic compounds have demonstrated remarkable success when addressing targets that have proved to be highly challenging for standard small-molecule drug discovery, especially in modulating macromolecular processes such as protein-protein interactions. Area of interest about Macrocyclic Chemistry of the scientists includes the theoretical studies, synthesis and characterization like crystallographic, spectroscopic thermodynamic studies etc. of new macrocyclic ligands and their complexes. Besides the uses in pharmacological sectors, macrocyclic compounds are also playing an important role in the field of Analytical Chemistry, industrial sector etc. Recently scientists are trying to use the different macrocyclic chelators in the selective isolation of radioactive materials from the waste matrix such as in isolation of radioisotopes of nickel $\left(\mathrm{r}-\mathrm{Ni}:{ }^{59} \mathrm{Ni},{ }^{63} \mathrm{Ni}\right)$ and cobalt $(\mathrm{r}-$ Co: ${ }^{60} \mathrm{Co}$ ) which are produced in the structural steels of nuclear reactor vessels and internal components from neutron activation of corresponding naturally occurring stable isotopes.

\section{Assets from publication with us}

- Prompt Acknowledgement after receiving the article

- Thorough Double blinded peer review

- Rapid Publication

- Issue of Publication Certificate

- High visibility of your Published work

Website: www.actascientific.com/

Submit Article: www.actascientific.com/submission.php Email us: editor@actascientific.com

Contact us: +919182824667 